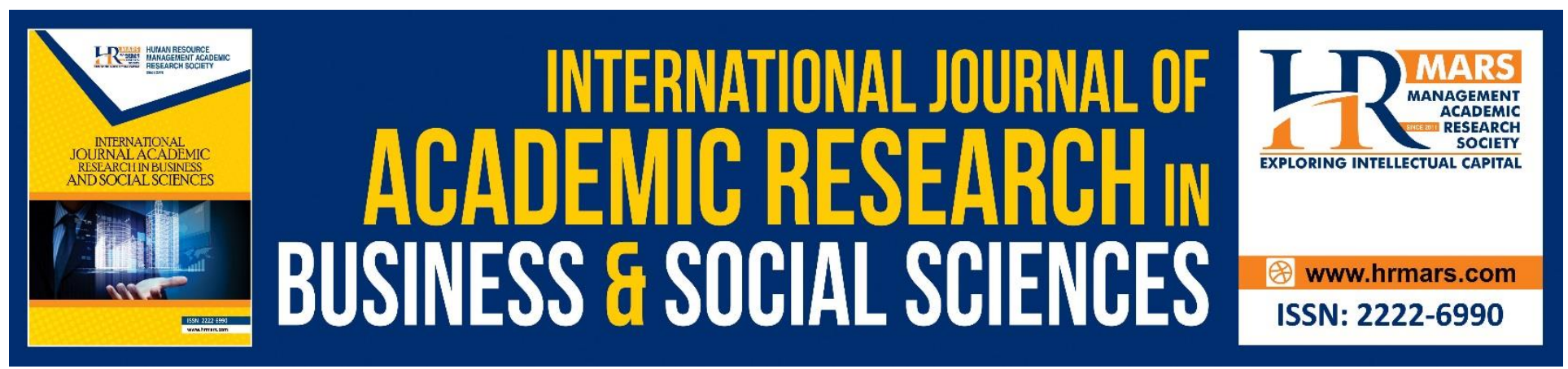

\title{
Decisions for Kiribati: An Economic Development Case Study
}

\author{
Brandon Walcutt
}

To Link this Article: http://dx.doi.org/10.6007/IJARBSS/v9-i3/5756

DOI: $\quad 10.6007 /$ IJARBSS/v9-i3/5756

Received: 24 Jan 2019, Revised: 23 Feb 2019, Accepted: 12 March 2019

Published Online: 23 March 2019

In-Text Citation: (Walcutt, 2019)

To Cite this Article: Walcutt, B. (2019). Decisions for Kiribati: An Economic Development Case Study. International Journal of Academic Research in Business and Social Sciences, 9(3), 937-944.

Copyright: (C) 2019 The Author(s)

Published by Human Resource Management Academic Research Society (www.hrmars.com)

This article is published under the Creative Commons Attribution (CC BY 4.0) license. Anyone may reproduce, distribute, translate and create derivative works of this article (for both commercial and non-commercial purposes), subject to full attribution to the original publication and authors. The full terms of this license may be seen at: http://creativecommons.org/licences/by/4.0/legalcode

Vol. 9, No. 3, 2019, Pg. 937 - 944

http://hrmars.com/index.php/pages/detail/IJARBSS

JOURNAL HOMEPAGE

Full Terms \& Conditions of access and use can be found at http://hrmars.com/index.php/pages/detail/publication-ethics 


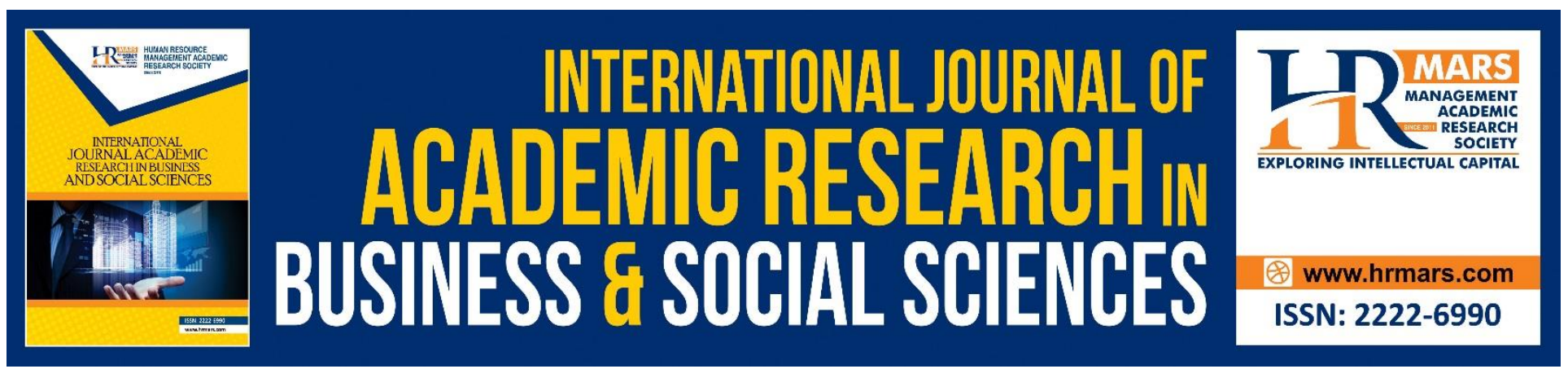

\title{
Decisions for Kiribati: An Economic Development Case Study
}

\author{
Brandon Walcutt \\ Department of Business, Cyber Security and Computer Sciences, Mohawk Valley Community \\ College, 1101 Sherman Drive, Utica, NY 13501, USA \\ Email: bwalcutt@mvcc.edu
}

\begin{abstract}
This teaching case pertains to the spending and development decisions that must be made concerning the disposition of a sizable fictional grant that has been provided to the Republic of Kiribati. The overall objective of the case is to provide students with the opportunity to apply their knowledge of international development, business and macroeconomics to determine a strategic direction for an economically challenged island nation in the Central Pacific. The case is oriented towards lower-level undergraduate students in a discipline relating to international development, policy or business and can be taught within a one-hour class with little or no outside student preparation. In particular, this case is well equipped at helping students receive a better understanding of the issues economically challenged nations face in the context of an International Growth and Development chapter in a Principles of Macroeconomics course.

Keywords: International Development, Republic of Kiribati, Government Policy Decisions, Strategic Government Goal Setting, Central Pacific Economic Development

\section{INSTRUCTOR NOTES}

Although the exercise can be completed by individual students, group work is suggested to maximize student learning. There are also no specific "right" answers for this case as all of the initiatives possess some degree of value to the Republic of Kiribati. However, instructors should focus their constructive criticism on the student's strategic goal(s) for the nation, their initiative and funding choices to achieve that goal, and the reasoning and assumptions behind student decisions.
\end{abstract}

At the instructor's discretion, the case can also be expanded to require actual student research into the country, its disposition and options. As noted on the case worksheets, all information provided within the case, other than the fictional grant, is based on the actual context and situation Kiribati is currently facing. 
One further suggestion that has improved student outcomes is the use of videos about Kiribati that are listed on Youtube.com. Youtube media, at the time of the writing of this case, include several tourism related videos of different lengths as well as some that are climate change oriented. Although the specific video can be left up to the discretion of the instructor, viewing even a few minutes allows the students greater understanding of the country and context and greatly improves the quantity and quality of participation.

\section{APPENDIX: CASE WORKSHEETS}

The referenced handouts in the appendix are to be distributed to the participating students as the primary materials for this exercise.

\section{Decisions for Kiribati: An Economic Development Case Study}

The Republic of Kiribati has been awarded a fictional five-year grant of $\$ 20$ million per year from an international organization. There were no stipulations regarding the use of the funds except that they be spent to better the lives of the people of Kiribati. Also, this money is outside the normal budget of the nation and, as such, can be spent strategically rather than simply being allocated towards shortterm expenses. Lastly, other than the fictional nature of the grant, all information provided within this case is based on the actual context and situation Kiribati is currently facing.

As you, the reader, are a part of the republic's Ministry of Development, it will be your task to provide recommendations to the senior minister as to the most strategic uses for the grant. To aid you in your task, ten potential initiatives have been identified as being the most beneficial for the nation. Analyze, select and allocate the grant funds to the initiatives based on the expected long-term benefits to the nation. The reasons and assumptions for your decisions will be required.

\section{Context}

The Republic of Kiribati consists of 109,000 people living on 33 islands and coral atolls in the Central Pacific. Possessing an Economic Exclusive Zone of roughly 3.6 million sq km, the country has a total land area of about $811 \mathrm{sq} \mathrm{km}$. Kiribati has a GDP of \$227 million and a real growth rate of 3.1\% (2017 est.) (Kiribati, 2019). The GDP is composed of agriculture focused mostly on copra and breadfruit production $(23 \%)$, industry relating to fishing and handicrafts $(7 \%)$ and various services $(70 \%)$ (Kiribati, 2019). In 2010, unemployment sidelined 30.6\% of the labor force (Kiribati Unemployment Rate, n.d.). Much of the government's revenue comes from earnings from fishing licenses (50\%) and remittances of workers abroad (6\%). However, the rest of the budget comes from foreign aid donated by countries such as Australia, New Zealand, the US and Japan (Kiribati, 2019).

Overall, the republic is seen as being one of the least developed countries in the world with a per capita GDP of only $\$ 2,000$ (Kiribati, 2019). Some of the primary developmental challenges faced by the country is the overall shortage of skilled workers, distance to potential markets, issues with energy and water and a general lack of infrastructure. 


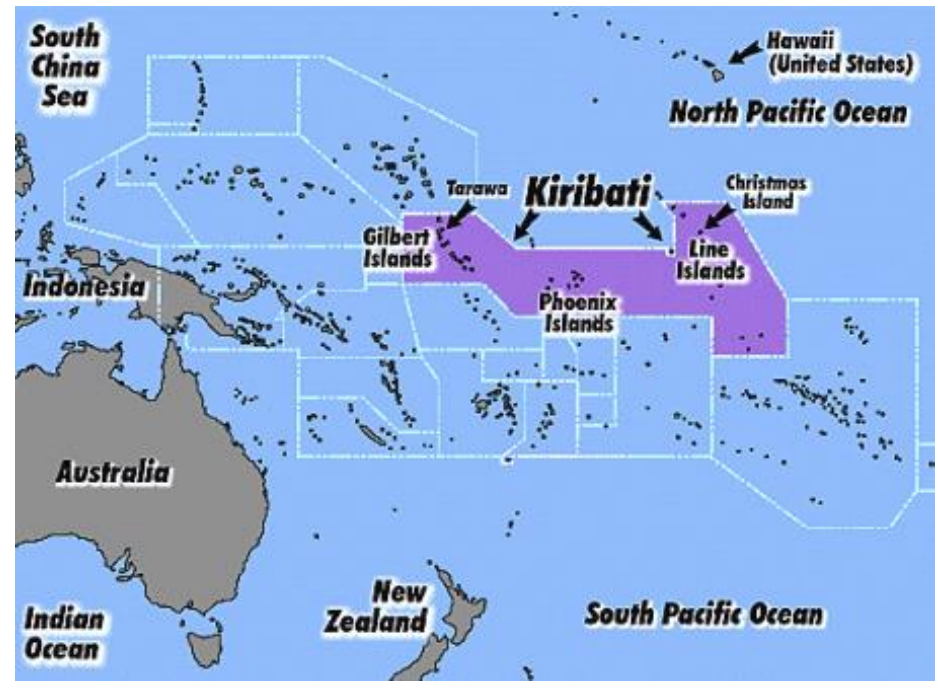

Map of the Republic of Kiribati

\section{Initiatives under Consideration:}

\section{Initiative 1 : Medical Services}

There are currently only .2 doctors per 1,000 citizens in Kiribati. This lack of medical care is a contributor to the average citizen life span of only 66.9 years. The deficit is also evident in the area of infant mortality where there are 31.1 deaths for every 1,000 live births (Kiribati, 2019). Additional doctors and improved medical facilities are in great demand.

$\%$ of Grant:

Reasons:

\section{Initiative 2 : Utility Improvement}

Water is a constant issue as the overall level of water consumption exceeds the nation's ability to provide fresh water and the current water infrastructure is lacking the ability to catch rainwater and store it. Sanitation is another major issue due to inadequate liquid and solid remediation facilities and the susceptibility for groundwater contamination. Lack of environmental awareness and legal framework are contributing factors.

$\%$ of Grant:

Reasons:

\section{Initiative 3 : Tourism Development}

Based on its weather, natural environment, and historical features, Kiribati has great potential to be developed into a mecca for tourism. In its current state, tourism contributes up to $20.9 \%$ of the nation's GDP and could be potentially much larger. It is expected that, by 2028 , upwards of $20 \%$ of all employment could result from the tourism industry (Travel \& Tourism, 2018). However, due to the lack of facilities and orientation, visitor numbers do not reach its true potential and it is said that those visitors must be prepared to "rough it" (Kiribati, n.d.). Improvements made to further develop tourism across Kiribati can provide a catalyst in growing the industry. 


\section{Initiative 4 : Human Resource Development}

Although Kiribati maintains a $91 \%$ basic literacy rate, the country's only institution of higher education, Kiribati Teacher College, is not able to provide the necessary training and human resource development to adequately support the country's initiatives, needs and industries (Health Service Delivery Profile - Kiribati, 2012), which forces most students seeking a university education to attend schools abroad and potentially never return. Additional emphasis in developing the nation's workforce in fields such as information technology and alternative energy technical skills must be undertaken if Kiribati is to fulfill its workforce needs in the future.

\section{\% of Grant: Reasons:}

\section{Initiative 5 : Coastal Management}

Poor land management practices and inappropriate or lacking coastal protection has led to severe erosion in many areas of Kiribati. The rising sea levels and storms of increasing power have also affected the nation through tidal surges and losses of fresh water. An example of the impact is the community of Bikenibeu on Tarawa Atoll, which is home to almost $7 \%$ of Kiribati's citizens. It is estimated that a 1'8" increase in sea level will result in the flooding of $71 \%$ of the island during a spring high tide (Bikenibeu, 2019). This flooding results in the reduction of atoll landmass as well as pollution of the remaining resources. Although somewhat expensive, improved education, management and the construction of barriers will reduce land loss and improve coastal sustainability (Kiribati Country Profile, 1988).

\section{\% of Grant: $\quad$ Reasons:}

\section{Initiative 6 : Information Technology and Communication}

The existing technological, phone and cellular system infrastructure is generally limited and expensive to use. Comparing Kiribati to the rest of the world, the percentage of citizens possessing fixed telephone lines, cellular phones and internet access is in the bottom $10 \%$ of the world's countries (Kiribati, 2019). Furthermore, there is a definitive lack of trained individuals to service the current, and especially future, estimated needs in these fields. Funding would enhance the current information technological base, allow greater access to the internet and enhance communication between the islands and abroad.

\section{\% of Grant: Reasons:}

\section{Initiative 7 : Natural Resource Development}

Within the nation's Exclusive Economic Zone (EEZ), there exists substantial estimated seabed deposits of manganese nodules and cobalt-rich manganese ore (Kiribati Country Profile, 1988). Although ore prices are currently relatively low and the deep-sea extraction technology is not well developed, it is hoped that building the appropriate infrastructure will encourage FDI in this sector of the economy and provide for a future growth engine. In addition to the investment requirements, this initiative will also require extensive legal and policy changes before any extraction can begin.

\section{\% of Grant: Reasons:}




\section{Initiative 8 : Renewable Energy}

At this time, only $59 \%$ of the population has access to electricity, and most of it is generated from expensive fossil fuel imports, which places a continuing drain on the economy (Kiribati, 2019; Kiribati Country Profile, 1988). Although $27 \%$ of all electricity, is generated from renewable energy sources, it is estimated that solar and wind energy generation could sustainably provide for all energy needs. However, the renewable energy infrastructure and expertise available on the islands is currently insufficient to allow for additional growth.

$\%$ of Grant:

Reasons:

\section{Initiative 9 : Defense}

Kiribati has no armed forces and only possesses one ocean-going patrol boat to cover the 3.5 million sq. kilometers of its EEZ. Although Kiribati currently has no major territorial disputes with its neighbors, it does have issues with poachers abusing its fisheries (Posts Tagged 'Kiribati Marine Protected Area', 2016). In 2014, 25\% of government revenue came from tuna access fees paid for by legal fisherman. However, illegal fishing could easily threaten that sizeable revenue stream (Wahlen, 2014). Kiribati could use additional patrol boats and the fuel to power them to police its EEZ to maintain the integrity of its marine resources.

\section{\% of Grant: $\quad$ Reasons:}

\section{Initiative 10 : Climate Change "Last Resort" Preparation}

Climate change is considered to be an assured threat by the government of Kiribati. There is no question as to whether it will impact the nation, but how greatly and how quickly. One alternative that has been somewhat adopted is the purchase of additional land in neighboring countries. This policy prompted Kiribati to purchase some land on Fiji in 2014 as it would allow some citizens to "migrate with dignity" when Kiribati's islands are eventually inundated by the sea (Ellsmoor \& Rosen, 2016). Any additional land purchases are expected to allow the nation to improve its food security and provide materials to assist in national building efforts. 
INTERNATIONAL JOURNAL OF ACADEMIC RESEARCH IN BUSINESS AND SOCIAL SCIENCES

Vol. 9, No. 3, March, 2019, E-ISSN: 222 2-6990 ¿ 2019 HRMARS

\section{Questions}

1. Based on the provided contextual and initiative specific information, what is your overall strategic vision for Kiribati?

2. To which initiatives will you allocate the funding from the grant?

\begin{tabular}{|l|l|l|l|l|l|l|}
\hline$\#$ & Initiative Name of Grant & $\#$ & Initiative Name & $\begin{array}{l}\text { of } \\
\text { Grant }\end{array}$ \\
\hline 1 & Medical Services & & & 6 & $\begin{array}{l}\text { Information Technology } \\
\text { and Communication }\end{array}$ & \\
\hline 2 & Utility Improvement & & 7 & $\begin{array}{l}\text { Natural Resource } \\
\text { Development }\end{array}$ & \\
\hline 3 & Tourism Development & & 8 & Renewable Energy & \\
\hline 4 & $\begin{array}{l}\text { Human Resource } \\
\text { Development }\end{array}$ & & 9 & Defense & \\
\hline 5 & Coastal Management & 10 & $\begin{array}{l}\text { Climate Change "Last } \\
\text { Resort" Preparation }\end{array}$ & \\
\hline
\end{tabular}

3. Reasons for your allocations above will be listed under each initiative on the following pages.

4. Will your funding allocations remain the same for the full five-year period of the grant? If not, list how/why the dispositions will change.

\section{References}

Chaoxiong, H. (December 2001). "Assessment of the Vulnerability of Bairiki and Bikenibeu, South Tarawa, Kiribati, to Accelerated Sea-Level Rise" (PDF). SOPAC Secretariat. Retrieved 18 March 2013. Ellsmoor, J. \& Rosen, A. (2016, January 11). Kiribati's land purchase in Fiji: does it make sense? . Retrieved December 30, 2016, from http://devpolicy.org/kitibatis-land-purchase-in-fiji-does-itmake-sense-20160111/.

Health Service Delivery Profile - Kiribati. (2012). Retrieved December 30, 2016, from http://www.wpro.who.int/health_services/service_delivery_profile_kiribati.pdf.

Kiribati. (n.d.). Retrieved December 30, 2016, from http://wikitravel.org/en/Kiribati.

Kiribati. (2019, January 5). Retrieved January 5, 2019, from

https://www.cia.gov/library/publications/resources/the-world-factbook/geos/ks.html.

Kiribati Country Profile. (1988). Retrieved December 30, 2016, from http://ict.sopac.org/VirLib/CP0005.pdf.

Kiribati Unemployment Rate. (n.d.). Retrieved December 30, 2016, from

http://www.indexmundi.com/kiribati/unemployment_rate.html.

Posts Tagged 'Kiribati Marine Protected Area'. (2016, January 18). Retrieved December 30, 2016, from http://eatingjellyfish.com/?tag=kiribati-marine-protected-area.

Travel \& Tourism Economic Impact 2018 Kiribati. (n.d.) Retrieved January 5, 2018, from https://www.wttc.org/-/media/files/reports/economic-impact-research/countries2018/kiribati2018.pdf. 
INTERNATIONAL JOURNAL OF ACADEMIC RESEARCH IN BUSINESS AND SOCIAL SCIENCES

Vol. 9, No. 3, March, 2019, E-ISSN: 222 2-6990 @ 2019 HRMARS

Wahlen, C. B. (2014, Aug. 7). WorldFish Report Discusses Fisheries, Food Security and Climate Change in Kiribati. Retrieved January 9, 2019, from http://sdg.iisd.org/news/worldfish-reportdiscusses-fisheries-food-security-and-climate-change-in-kiribati/. 